\title{
Capital Structure and Financial Control: The Effect of Leverage on Project Management
}

\author{
${ }^{1}$ Fuzhi Zhou, ${ }^{2}$ Haidong Feng, ${ }^{3}$ Alina Gaile \\ ${ }^{1}$ School of Finance, Lanzhou University of Finance and Economics, \\ Lanzhou, China, \\ ${ }^{2,3}$ Faculty of Economics and Management, University of Latvia, Riga, Latvia
}

\begin{abstract}
Amplification characteristics are leveraging financial system which has a small risk of capability. However, the efficiency of this ability is the two-ways result and will also pose a lot of risks. Therefore, taking positive measures to strengthen the management of the financial system leverage feature in project management becomes very important. This paper describes the financial system leverage to bring the main problem through the lever amplification (nature) analysis of the characteristics, bi-amplified comparative analysis of profit and loss and bi-amplification characteristics of the risk analysis. Based on the above analysis, we put forward countermeasures about the management of leverage properties of a financial system from the application of project management.
\end{abstract}

Keywords: Financial system, Project management, Leverage characteristic, Leverage category management

\section{INTRODUCTION}

Contemporary evolution of the financial system in the outstanding performance that first developed rapidly is mixed. This is largely due to its real economic leverage amplification characteristics. It is the leverage performance of the financial system, so it has a small risk of capacity, particularly under the effect of high leverage efforts that people often anticipate. Two financial derivatives, for example, under ordinary circumstances investors only need to pay a small deposit that can carry a huge amount of the transaction. On one hand, it can make the money work more efficiently in project management and avoid risks to achieve hedge of gaining huge profit. On the other hand, the financial derivative transactions or probability also contain a huge risk of losing occurs when the amount loss is correspondingly expanded several times, and its ripple effect will be spread like dominoes away, and it will be difficult to contain it. One of the reasons of the global financial crisis is that five largest investment banks of U.S annihilated in the same time.

Financial system leverage amplification in the application of project management (characteristics) is possible in two ways because it more often becomes a "double-edged weapon". On the one hand, it promotes the efficient operation of financial markets; on the other hand, it brings high leverage effect which is also exacerbating the financial market fluctuations. Thus, the endeavor is to take positive measures to strengthen the leverage characteristics and quantitative indicators of project management. It became very important nowadays. 


\section{FINANCIAL SYSTEM LEVERAGE TYPES AND QUANTITATIVE INDICATORS}

The financial system of the real economy leverage amplification characteristics of a variety of different forms. In coordination with the role of different areas, it can be classified as the capital in nature and the nature of the transaction leverage. Corresponded quantitative indicators can be divided into capital and transactional leverage. The main capital gearing types are risk-sensitive leverage ratio - capital adequacy, and risk-insensitive leverage ratio - (financial) leverage. General capital adequacy ratio is defined as total capital divided by total risk-weighted assets ratio. Also, associated with the capital adequacy ratio and core capital adequacy ratio, namely, the core capital is divided by total risk-weighted assets ratio. According to the China Banking Regulatory Commission requirements (financial), leverage ratio refers to commercial banks to hold, in line with the relevant provisions of capital with assets ratio's adjusted balance sheets of commercial banks. By comparison with it, we can see that the main difference between these two gearing types lies in the denominator, and the former is based on the risk-weighted assets, while the latter is based on the total assets.

Trading with the main types of leverage margin (ratio) and premiums (rates) plays the main role in a variety of credit guarantee transaction process and is widespread in spot trade, futures trading, and options trading. The latter point in a variety of transaction process will be the decision-making right in the future, which will give the opportunity to choose the right to determine the point in the delayed time, as well as the beneficial or contingent event, instead of pointing to the subject matter of the transaction itself.

By the U.S. sub-priming mortgage, crisis, triggered by the global financial crisis, has exposed a variety of financial institutions and financial derivatives excessive accumulation of leverage after the negative effects, promoting people to leverage the ability of the financial system (characteristics) of the regulation for reflection. December 2010 by the release of Basel III, it has raised previous Basel capital adequacy requirements; June 2011 it has introduced a pair of systemically important bank's supplementary capital ratio requirements. And in 2012 the country began to implement "commercial bank's capital management approach". It is more than a series of Basel III capital requirements are more stringent (see Table 1) so far.

Table 1: Minimum Capital Requirements of Banks Abroad

\begin{tabular}{|c|c|c|c|}
\hline $\begin{array}{c}\text { Domestic and } \\
\text { International }\end{array}$ & \multicolumn{3}{|c|}{ Minimum Capital Adequacy Requirements } \\
\hline \multicolumn{1}{|c|}{ Regulations } & $\begin{array}{l}\text { Core Tier One } \\
\text { Capital }\end{array}$ & First Grade Capital & Total Capital \\
\hline Basel III & $4.5 \%$ & $6 \%$ & $8 \%$ \\
\hline China Banking 2012 & $5 \%$ & $6 \%$ & $8 \%$ \\
\hline
\end{tabular}

Source: BCBS (2010a), China Banking collate relevant information

At the same time, in order to control the leverage effect (characteristics) to excessive accumulation of the banking sector to avoid future when the deleveraging on the entire financial system and the real economy, resulting in greater impact, Basel III also explicitly provides the leverage lower limit requirements (as $\geq 3 \%$ ), while China is also higher than the corresponding provisions of this rigorous (as $\geq 4 \%$ ). Basel III required the calculation of the leverage ratio, the bank's risk exposure estimates include both sheet items (such as derivatives trading, etc.), but also include off-balance sheet items (such as loan commitments, direct credit substitute, etc.). In the New Basel Capital Framework agreements established under the capital adequacy ratio and leveraged the synergy of modern banking regulation that became effective control characteristics of the main means of leverage. 


\section{THE MAIN PROBLEMS OF FINANCIAL LEVERAGE SYSTEM}

\subsection{Strengthening the Financial System to the Real Economy Reaction Ability}

Leverage which has been made over the years is based on the rapid development of the project management; moreover, more than the speed of the development of the project management itself. It makes the size between the two top-heavy "layers" of "inverted pyramid" one of the consequences. These consequences lead to the frequent grows and falls. The financial system in a bull market has all kinds of asset value, causing liquidity; once the financial system is in a bear market, all kinds of assets impairment, causing a liquidity crunch.

\section{2. "Bidirectional Amplification" Lever Characteristics of Coexisting Advantages and Disadvantages}

In the financial system of the trading, profit and one of the main reasons are that often there is a high leverage, not only derived type is commonly used while trading, recent years foundation type deal is also widely used. Ability to leverage amplification (features) of the financial system is one of its characteristics and is also one of the "advantages". The problem is that this kind of amplification ability (features) is a two-way street, which can not only enlarge profit but also magnify the loss, even if very large financial institutions will continue being because of a department or because of business's local loss, which will be caused by integrity. Such financial leverage as Lehman Brothers, which's rate grew up in the first quarter of 2008 in 31.7 times, make sub-prime securities losses small changes later led to a net worth of losses, eventually became "the last straw breaks the camel's".

\subsection{The Superposition of Multiple Combinations of Making the Nature of Leverage (features)}

The financial system of the trading tools combined with derivative will greatly change the lever of original features and make it even harder to identify and measure the risk of future. ARM and contain the subprime MBS, for example, the original form is relatively simple that will help us to safe mortgages and mortgage-backed securities. But the commercial Banks, to revitalize the capital investment bank, will expand business scale. The institutional investors, which are seeking for higher returns, will jointly contribute to the CDOs (collateralized debt obligations (CDO), CDOs and a series of multiple packaging of derivatives, for expanding the influence of subprime mortgages, which are spreading over. It can effectively reduce the risk of products and, as a result, spread into specific risk and magnify systemic risk products.

\subsection{The Main Problems of the System (Only Leading to Moving Back and Forth Not Reducing the Risk)}

The modern financial system is independent of the real economy running trend, which is becoming more and more obvious. Pursuing of tools leverage efficiency and industry scale makes its trading operation from general enterprises, organizations, and makes retail investors give priority to institutional investors. In addition to hedge funds, mutual funds and pension funds, the issue of MBS policy is based on financial institutions such as Fannie Mae and Freddie MAC, CDOs, an investment bank, management of the CDS (credit default swaps) insurance company (AIG), even the original mortgage selling assets of commercial Banks has become kind of financial instruments, especially the huge derivative securities holders. It shows more and more independence of entity economy of the project management, more and more large-scale financial business, mainly in the various financial institutions between inside trading and follow later transfer process, rather than risk foreign dispersion process in the true sense. 


\section{FINANCIAL SYSTEM ABILITY LEVERAGING OF THE AMPLIFICATION (ANALYSIS OF THE CHARACTERISTICS)}

Leveraging "characteristics of the financial system (nature)" is mainly done through the financial tools between the "copy" and the substitute for each other; this is also enhancing the efficiency of the financial system, which is one of the main ways to reduce the transaction costs. Financial instruments and their replication are intermediate tools, alternative tools while you can do it with the same cash flow, but their implicit yields and risk characteristics are not always the same. For example, you can buy a unit stock call option and put option to sell a unit stock copy the stock of cash flow, the call option and put option with the same $S$, maturity $T$, and the asset price $X$ European option, as is shown in figure 1 . We always say call option and put option $c$ and $p$ for short, the price of the tectonic replicate stock cost is $c-p$. In the options of maturity $T$, the value of the replica VT is valued call option and put option value, the difference between the namely

$$
\mathrm{V}_{\mathrm{T}}=\max \left(0, \mathrm{~S}_{\mathrm{T}}-\mathrm{X}\right)-\max \left(0, \mathrm{X}-\mathrm{S}_{\mathrm{T}}\right)
$$

If due date ST stock price is greater than the strike price $X$, then call option value is ST - X, put option value is zero; If the ST is less than $X$, the call option value is zero, the put option value is $X-S T$. Therefore, no matter how the future stock price changes, a copy of the stock in this combination in the value of the option maturity date is always | ST - X |. If only considering replicate stock structure cost without considering the time value of money, then the replication tool at the end of profit and loss is:

$$
\operatorname{Max}(0, S T-X)-\operatorname{Max}(0, X-S T)-(c-p)=S T-X-c+p \text {. }
$$

\begin{tabular}{|c|c|c|c|c|}
\hline \multirow{2}{*}{$\begin{array}{l}\text { The Type of } \\
\text { Transaction }\end{array}$} & \multirow[b]{2}{*}{ Capital } & \multirow{2}{*}{$\begin{array}{l}\text { Leveraged } \\
\text { Nature }\end{array}$} & $\begin{array}{c}\text { The Price Rise in } \\
\text { Net }\end{array}$ & \multirow[b]{2}{*}{ Yield Rate } \\
\hline & & & Profit or Loss & \\
\hline Spot Transactions & \begin{tabular}{|l|}
100 \\
\end{tabular} & $1: 1$ & $110-100=10$ & $10 \%$ \\
\hline Future Transactions & 100 & Cash Deposit 10\% & $(110-100) \times 10=100$ & $100 \%$ \\
\hline $\begin{array}{l}\text { The Option } \\
\text { Combinations }\end{array}$ & 100 & The Total Cost $1 \%$ & $\begin{array}{c}(110-100- \\
1) \times 100=900\end{array}$ & $900 \%$ \\
\hline
\end{tabular}

Table 2: The financial system of leveraging features when prices rise $10 \%$

Source: Authors' construction

Table 3: Financial system leverage amplification characteristics when prices have fell by $10 \%$

\begin{tabular}{|l|c|c|c|c|}
\hline & & & $\begin{array}{c}\text { The Price Rise in } \\
\text { Net }\end{array}$ & \multirow{2}{*}{$\begin{array}{c}\text { The Type of } \\
\text { Transaction }\end{array}$} \\
\cline { 1 - 2 } & Capital & $\begin{array}{c}\text { Leveraged } \\
\text { Nature }\end{array}$ & Profit or Loss & Yield Rate \\
\hline Spot Transactions & 100 & $1: 1$ & $90-100=-10$ & $-10 \%$ \\
\hline Future Transactions & 100 & $\begin{array}{c}\text { Cash Deposit } \\
10 \%\end{array}$ & $(90-100) \times 10=-100$ & $-100 \%$ \\
\hline $\begin{array}{l}\text { The Option } \\
\text { Combinations }\end{array}$ & 100 & $\begin{array}{c}\text { The Total Cost } \\
1 \%\end{array}$ & $(90-100-1) \times 100=-1100$ & $-1100 \%$ \\
\hline
\end{tabular}

Source: Authors' construction 
The principal amount of the same circumstances, the financial system in spot trading, futures trading, and options trading yield difference are consisted now of three ways, from the perspective of the nature of the leveraged financial system to make the corresponding comparison, as shown in table 2 and table 3. Thus, it can be seen that when using different financial instruments traded, because of their leverage performance difference, net profit or loss brought by the difference is huge. Also its risk can also be completely different.

\section{Financial System and Contrast Analysis of the Bidirectional Amplification}

The financial system of contract type can be divided into two major categories of symmetric and asymmetric agreement: contract revenue - risk of distribution is also varied with the type of different one. Basic financial products and forward derivatives (including forwards, futures, swaps) contracts are symmetric. If a T for the session (maturity date), the asset of Mark ST (maturity date) to the market price of the trading day, $\mathrm{K}$ for the agreed price, delivery, long profit or loss, which the buyer gains and losses, short of symmetric contracts and losses of the seller's profit and loss as shown in figure 2 (a), (b), and lists of their profit upper limit and lower limit losses.

When $\mathrm{S}_{\mathrm{T}}>\mathrm{K}$, Symmetric long contract value: $\mathrm{V}=\mathrm{S}_{\mathrm{T}}-\mathrm{K}>0$. Symmetric contracts bulls and losses of the profit limit: $V_{\max } \rightarrow+\infty$.

When $\mathrm{K}>\mathrm{S}_{\mathrm{T}}$, Symmetric long contract value: $\mathrm{V}=\mathrm{K}-\mathrm{S}_{\mathrm{T}}>0$. Symmetrical short contracts and losses of the maximum profit: $\mathrm{V}_{\max }=\mathrm{K}$.

When $\mathrm{S}<\mathrm{K}$, Symmetric long contract value: $\mathrm{V}=\mathrm{S}_{\mathrm{T}}-\mathrm{K}<0$.

Symmetric contract bull losses and losses of the lower limit: $\mathrm{V}_{\min }=-\mathrm{K}$.

When $\mathrm{K}<\mathrm{S}_{\mathrm{T}}$, Symmetric long contract value: $\mathrm{V}=\mathrm{K}-\mathrm{S}_{\mathrm{T}}<0$.

Symmetrical short contracts and losses of the loss limit: $\mathrm{V}_{\min } \rightarrow-\infty$.
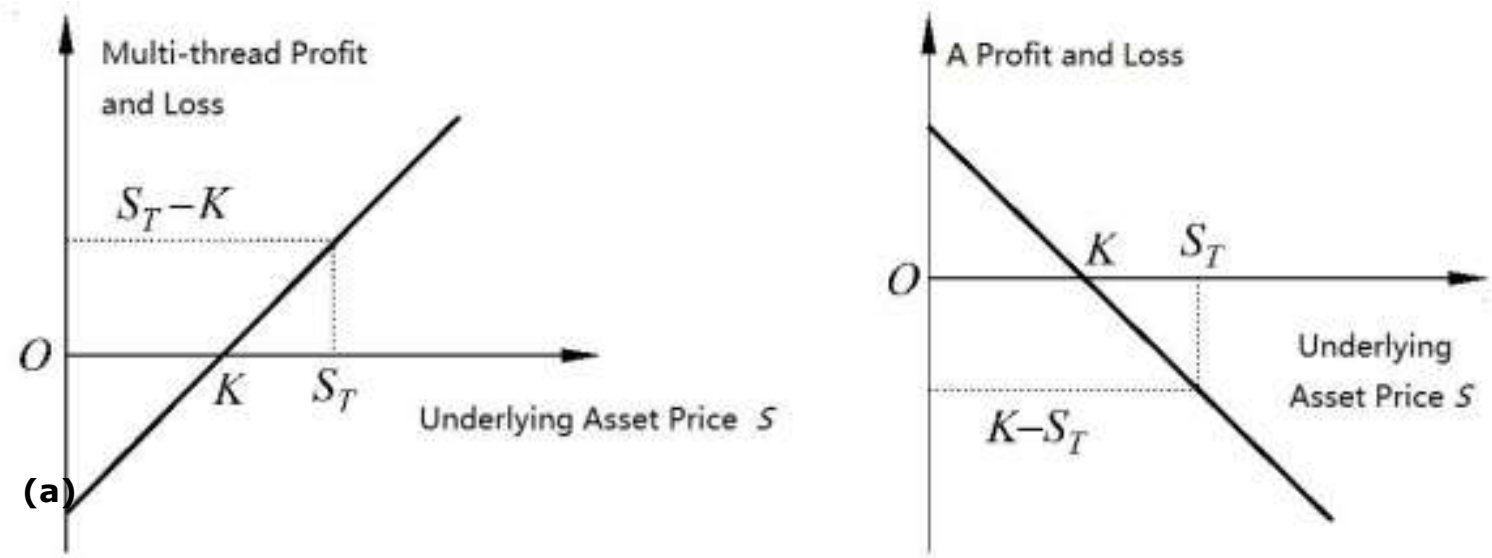

Symmetric Long Profit and Loss of Contracts (b) Symmetry Short Profit and Loss of Contracts

Figure 1: Symmetric Contracts of the Long and Short of Comparative Analysis

Source: Authors' construction

For asymmetric contracts - short of an options contracts short call option and put option value, respectively as shown in figure 4 (a), (b), and lists the respective profit upper limit and lower limit losses.

When $\mathrm{S}_{\mathrm{T}}>\mathrm{X}$, short call option value: $\mathrm{V}=\mathrm{X}-\mathrm{S}_{\mathrm{T}}+\mathrm{c}$. When $\mathrm{X}>\mathrm{S}_{\mathrm{T}}$, short put option value: $\mathrm{V}=\mathrm{S}_{\mathrm{T}}-\mathrm{X}+\mathrm{p}$. 
Short call options and losses of the loss limit: $V_{\min } \rightarrow-\infty$. Short put options increase and decrease loss limit: $V_{\min }=-X+p$.

When $\mathrm{S}_{\mathrm{T}}<\mathrm{X}$, short call option value: $\mathrm{V}=\mathrm{c}$. When $\mathrm{X}<\mathrm{S}_{\mathrm{T}}$ short put option value: $V=p$.

Short call options and losses of the maximum profit: $V_{\max }=c$ Short put option and losses of the maximum profit: $\mathrm{V}_{\max }=\mathrm{p}$

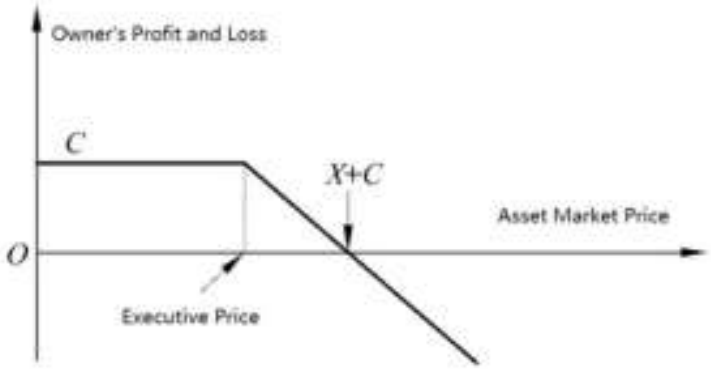

(a) Short of Profit and Loss of the Call

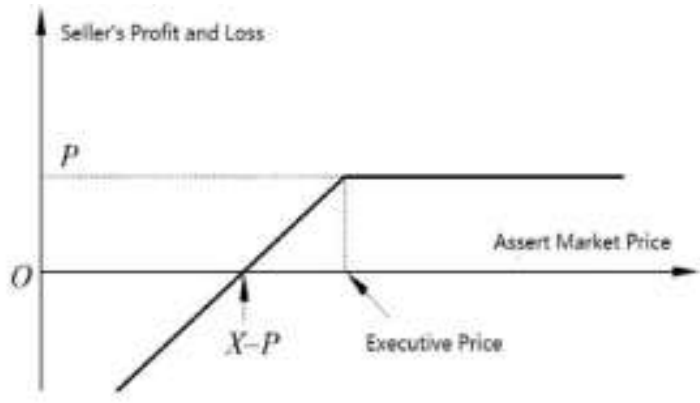

(b) Short Put Option of the Profits and Losses

Figure 2: Options Contract's Short Comparative Analysis

Source: Authors' construction

\section{FINANCIAL SYSTEM OF THE BIDIRECTIONAL AMPLIFICATION CHARACTERISTICS OF RISK ANALYSIS IN PROJECTS}

Through the above comparison and analysis of profit and loss of the financial system we can see that very different contracts can be found, under the condition of transaction costs to be ignored, the financial system of all kinds of trades is a zero-sum game; If it is included in the transaction costs, many of the financial systems can even become a "negative and game". When the direction of the transaction itself change the "empty" replacement, it is not only benefit/risk reversal, and its earnings/risk limit will be completely reversed.The properties of the resulting risk of sudden would be very great. In the previous financial crisis, it had such instance.

Table 4: Long and Short Profit Maximum of Limit

\begin{tabular}{|l|c|c|}
\hline Contract Type & Long Profit Upper Limit & Short Profit Upper Limit \\
\hline Forward Contracts & $\mathrm{V}_{\max } \rightarrow+\infty$ & $\mathrm{V}_{\max }=\mathrm{K}$ \\
\hline Futures Contract & $\mathrm{V}_{\max } \rightarrow+\infty$ & $\mathrm{V}_{\max }=\mathrm{K}$ \\
\hline Swap Contract & $\mathrm{V}_{\max } \rightarrow+\infty$ & $\mathrm{V}_{\max }=\mathrm{K}$ \\
\hline Call Option & $\mathrm{V}_{\max } \rightarrow+\infty$ & $\mathrm{V}_{\max }=\mathrm{c}$ \\
\hline Put Options & $\mathrm{V}_{\max }=\mathrm{X}-\mathrm{p}$ & $\mathrm{Vmax}=\mathrm{p}$ \\
\hline
\end{tabular}

Source: Authors' construction

For long-short, both sides of the financial system faced the risk by the nature of the differences that can be controlled by table 4, table's five loss limit comparison to contrast (in derivative contracts, for example). Among them, the standardization of futures trading can be the regard as the forward transactions. For swaps, according to the habit of swap market, will be paid at a fixed interest rate, 
the party in a floating interest rate as a "buy" interchangeably, for long; will pay a floating interest rate, the party in a fixed rate as a "sell" interchangeably, for short. Agreed delivery price for K fixed interest rate, maturity date to the market price of ST for a floating interest rate.

In the table we can see the limit of the profit and loss formula for many derivative transactions, the profit is mostly on the "cap" (+ up), losses "is always a bottom" $(-K,-c,-p)$.

But for short, is profitable "always limited" ( $K, C, p)$, losses are mostly (up) is not guaranteed. Thus, the risk of "short" than "long", if it is a cross trade, the risk will be bigger.

Table 5: Long and Short Loss Maximum of Limit

\begin{tabular}{|c|c|c|}
\hline Contract Type & Long Loss Maximum & Short Loss Maximum \\
\hline Forward Contracts & $\mathrm{V}_{\min }=-\mathrm{K}$ & $\mathrm{V}_{\min } \rightarrow-\infty$ \\
\hline Futures Contract & $\mathrm{V}_{\min }=-\mathrm{K}$ & $\mathrm{V}_{\min } \rightarrow-\infty$ \\
\hline Swap Contract & $\mathrm{V}_{\min }=-\mathrm{K}$ & $\mathrm{V}_{\min } \rightarrow-\infty$ \\
\hline Call Option & $\mathrm{V}_{\min }=-\mathrm{c}$ & $\mathrm{V}_{\min } \rightarrow-\infty$ \\
\hline Put Options & $\mathrm{V}_{\min }=-\mathrm{p}$ & $\mathrm{V}_{\min }=-\mathrm{X}+\mathrm{p}$ \\
\hline
\end{tabular}

Source: Authors' construction

\section{CONCLUSION}

To sum up, the financial system that has two-way leverage amplification characteristics and is based on the project has a huge backlash. The levers of different natures and leverage amplification characteristics of high and low will affect the stability of the financial system and the size of the risk. To this it can be modeled on the effective method of five-classification management of credit assets category, the financial system of the lever also features five classification management, including five classification management's internal operations and the department in charge of five classification regulation external category. Anticipation for the function is different from the capital property of leverage and trading in various leveraged levels of the lower limit and upper limit respectively (the following quantitative indicator levels correspond to the Basel agreement, due to the length limit, its specific measurements were considered in the article). Capital leverage of the quantitative indicators can select sensitive to risk ratio - the ratio of capital adequacy ratio is not sensitive to the risk type (financial) leverage two; Trading leveraged quantitative indicators can be selected for the security deposit (rate) or royalties (rate).

The first is in the "normal" state of the system financial institution or trading process. Institutions of capital adequacy ratio have to reach $10 \%$ or higher level; the leverage ratio has to reach $4 \%$ or higher level; Margin trading process (rate) have to reach $12 \%$ or higher level. For the system of financial institutions in the class of "normal" or trading process, regulators through routine statistics and collect information, to master the general situation.

The second is in a state of "attention" of the financial system or process. Institutions of capital adequacy ratio have to reach $8-10 \%$ or higher level; the leverage ratio has to reach $3-4 \%$ or higher level; Margin trading process (rate) have to reach $8-12 \%$ or higher level. For the system of financial institutions in the class of "attention" or trading process, except through the regulatory department's statistics summary related tables outside the area, in which the financial institutions should also require mark-to-market calculating the exposure.

The third class is in a state of "high concern" financial institutions or trading process. Institutions of capital adequacy ratio have to reach $6-8 \%$ or higher level; the leverage ratio has to reach $2-3 \%$ or higher level; Margin trading process (rate) have to reach $5-8 \%$ or higher level. In the class of 


\section{Fuzhi Zhou, Haidong Feng, Alina Gaile}

\section{Capital Structure and Financial Control: The Effect of Leverage on Project Management}

"attention" or trading process for the system of financial institutions, , regulatory authorities have to require financial institutions to pay attention to the related credit, market, operation risk of comprehensive management, and submit the data classification, the different trades for purpose of setting up a different account between "firewall", and submitting the regulatory risk on a regular basis.

The fourth class is in a state of "limit" of the system financial institution or trading process. Institutions of capital adequacy ratio have to reach $4-6 \%$ or higher level; the leverage ratio has to reach $1-2 \%$ or higher level; Margin trading process (rate) have to reach $2-5 \%$ or higher level. For the "restriction" system of financial institutions or transaction, leverage effect significantly, regulators have to take exception to the regulatory way and to set up a targeted leverage multiple threshold limit value. As a result, the value net of delivery will be limited to qualified investors.

The fifth class is in a state of "no" financial institutions or trading process. When Institutions of Capital Adequacy Ratio is $<4 \%$, leverage ratio is $<1 \%$; Margin trading process (rate) is only $2 \%$ for the "prohibition" of the class system of financial institutions or transaction process, due to the high leverage. Such risks beyond current regulatory ability, once the reverse market move, not only make the individual institutions in trouble, and will also spill over to other institutions, so besides a few in the middle, which must be banned. If we have a better understanding of this problem in the future, we could open appropriate again, but only after we introduce more effective means of regulation in project management.

\section{REFERENCES}

- Alexandridis A.K, Zapranis A.D., 2014. 9. Modeling Financial Wind Derivatives [J]. Wavelet Neural Networks: With Applications in Financial Engineering, Chaos, and Classification.

- Beder T, Marshall C M, Bernard L., 2012. Appendix A: It Tools for Financial Asset Management and Engineering [J]. Financial Engineering: The Evolution of a Profession.

- Brigham E.F., Tapley T.C., 1985. Financial Leverage and Use of the Net Present Value Investment Criterion: A Reexamination [J]. Financial Management (1972), 14(2), pp. 48-52, CrossRef

- Byoun S., Kim J., Yoo S.S., 2013. Risk Management with Leverage: Evidence from Project Finance [J]. Journal of Financial and Quantitative Analysis, 48(2), pp. 549-577, CrossRef

- Casas C.A., Casas C.A., 2012. Parallelization of artificial neural network training algorithms: A financial forecasting application [J]. 2012 IEEE Conference on Computational Intelligence For Financial Engineering \& Economics (CIFER), 430, pp. 337-342, CrossRef

- Chatterjee R., 2014. Practical methods of financial engineering and risk management: tools for modern financial professionals. Quantitative finance series. Hua-ping Z., Suo-di Z., Ying-dong J., 2014. Analysis on Talent Training Mode for Engineering Management Specialty in Financial and Economic Universities [J]. Journal of Higher Education Finance.

- Jianyun G., 2004. On financial management in road maintenance engineering [J]. Shanxi Architecture. Jugdev K., Mathur G., 2012. Classifying Project Management Resources By Complexity And Leverage [J]. International Journal of Managing Projects in Business, 2012, (1).

- Laux C., Loranth G., Morrison A.D., 2014. The Adverse Effect of Internal Control on Governance and Leverage [J]. Social Science Electronic Publishing.

- Ling-fang W., 2012. Exploration on Financial Management Mechanism in Engineering Supervision Enterprise [J]. Modern Industrial Economy and Informationization.

- Ramaprasad A., Prakash A.N., 2003. Emergent project management: how foreign managers can leverage local knowledge [J]. International Journal of Project Management, Vol. 21, pp. 199-205(7).

- Wang C., Liu H., Hsieh C., 2014. Rate-sensitive leverage of QoS and QoP for ubiquitous video streaming via buffer-aware feedback control [J]. Multimedia Tools and Applications, 73(2), pp. 737-761, CrossRef 


\section{Fuzhi Zhou, Haidong Feng, Alina Gaile}

Capital Structure and Financial Control: The Effect of Leverage on Project Management

- Xianzhong S, Lijun T., 2010. The Separation of Control Rights and Cash Flow Rights, Leverage and Corporations' Investment [J] Research on Economics and Management

- Yi L., 2007. Consideration on the Agent-construction System Practice in Engineering Management and Financial Management [J] Construction Economy 